\title{
Policy feedback in the local context: analysing fairness perceptions of public childcare fees in a German town
}

\author{
Marius R. Busemeyer ${ }^{1}$ and Achim Goerres ${ }^{2 *}$ \\ ${ }^{1}$ Department of Political Science and Public Administration, University of Konstanz, Germany and \\ ${ }^{2}$ Institute of Political Science, University of Duisburg-Essen, Germany \\ ${ }^{*}$ Corresponding author. Email: Achim.Goerres@uni-due.de
}

(Received 31 August 2017; revised 8 December 2018; accepted 20 December 2018;

first published online 22 February 2019)

\begin{abstract}
This article studies local processes of policy feedback by analysing citizens' fairness perceptions of public childcare fees in a German town. Employing an experimental vignette study, we uncover complex feedback effects: first, citizens in the study regard a fee level as fair that is close to the actual fee level in the city, suggesting self-reinforcing feedback effects. Second, citizens strongly support a fee structure in which fees vary according to parental income. As this preferred fee structure differs from the local fee structure in the town itself, we interpret the citizens' preference as evidence for selfundermining policy feedback. Finally, the actual characteristics of the respondents matter less than the fictitious characteristics of the parents in the vignettes, which points to the importance of interpretive rather than resource-based feedback effects. In concluding, we highlight the relevance of these findings for broader debates about policy feedback.
\end{abstract}

Keywords childcare; fairness; fees; Germany; policy feedback; vignette experiment

Our empirical case is an analysis of fairness perceptions in a particular German town Konstanz and which we will describe in greater detail below. We focus on a particular town for a simple reason: fee levels and the structure of fee-paying schemes vary enormously across German municipalities (Goerres and Tepe 2013). Focussing on a particular case allows for a detailed analysis of the different feedback effects at the individual level while holding the macrocontext constant. It also concentrates research resources on a single, high-level-quality survey. Another issue to consider is that measuring fairness perceptions of fees is empirically challenging. Conventional international comparative surveys of public opinion do not contain a lot of information about public attitudes towards the provision of childcare, let alone information about childcare fees. Furthermore, asking complex questions about policy design (the structure of fee systems) could be asking too much of some respondents, leading to biased responses. Therefore, we used a vignette survey experiment to derive assessments of both the level of childcare fees

(C) Cambridge University Press 2019. This is an Open Access article, distributed under the terms of the Creative Commons Attribution licence (http://creativecommons.org/licenses/by/4.0/), which permits unrestricted re-use, distribution, and reproduction in any medium, provided the original work is properly cited. 
which would be regarded as fair, as well as the institutional design of the fee scheme.

Briefly, this article aims to contribute to the broader debate about policy feedback by providing a detailed analysis of different kinds of feedback mechanisms. To foreshadow our main findings: first, we find that citizens consider a level of childcare fees as fair that was slightly below the actual level of fees at that time. We interpret this as an indication of a self-reinforcing normative/interpretive policy feedback, as the accepted level of fees is quite close to the actual level. Second, we find evidence for a self-undermining interpretive feedback effect regarding the fee structures. In Konstanz, childcare fees are independent of parental income (with exceptions for parents on social assistance). Instead of supporting income-independent fees, however, citizens in our survey clearly consider a fee model as fair in which the fee level is dependent on parental income as well as other resources. Third, the notion of resource-based feedback would suggest that wealthy citizens should be opposed to income-dependent fees. Contrary to this expectation, we find that the rich are at least as likely to support income-dependent fees as the poor. Thus, our analysis shows that different kinds of feedback effects can be observed at the same time. Therefore, rather than focussing on which type of policy feedback dominates overall, our analysis suggests that researchers should try to understand better the particular features of the institutional context that may trigger different kinds of feedback dynamics at the individual level.

\section{Literature review}

This article broadly connects to the extensive literature on public opinion about the welfare state, which has grown significantly in recent years in line with the increasing availability of high-quality international comparative survey data; see Svallfors (2012) for a recent overview. As a consequence, scholarly knowledge about the individual and institutional determinants of welfare state attitudes has increased enormously. First, scholars have repeatedly found that material selfinterest influences individual-level policy preferences to a significant extent (see e.g. Meltzer and Richard 1981; Iversen and Soskice 2001; Cusack et al. 2006; Busemeyer et al. 2009; Rehm 2009; Hacker et al. 2013; Margalit 2013; Kitschelt and Rehm 2014; Schwander et al. 2015). For instance, wealthy citizens were more likely to oppose welfare spending (Meltzer and Richard 1981; Rehm et al. 2012); those with "specific skills" were more likely to support it (Iversen and Soskice 2001; Cusack et al. 2006), as were those facing higher levels of labour-market risk (Rehm 2009; Rehm et al. 2012). The elderly were found to be more opposed to spending on education (Busemeyer et al. 2009), whereas the young, educated middle-classes were more supportive of social investment policies (Schwander et al. 2015). Second, scholars have repeatedly pointed out that, besides self-interest, normative orientations and values also shape policy attitudes and preferences, e.g. altruism, political ideology and religiosity, as well as different perceptions of fairness, deservingness and social justice (Kangas 1997; Alesina and Angeletos 2005; Scheve and Stasavage 2006; De La O and Rodden 2008; Margalit 2013). Third, the literature has paid particular attention to the question of how institutional contexts shape preferences and attitudes at the individual level. A first wave of scholarship concentrated on how welfare state regimes, broadly conceived as configurations of macro-level institutions, are reflected in individual attitudes towards the welfare 
state (Svallfors 1997; Andreß and Heien 2001; Blekesaune and Quadagno 2003; Svallfors 2004; Jaeger 2006; Jaeger 2009; Svallfors 2010; Svallfors 2012). The initial expectation that preferences would be largely congruent with macro-level institutions was not entirely borne by the data (Jaeger 2006; Jaeger 2009). Hence, more recent contributions to the literature focus on particular institutional dimensions of the welfare state rather than on broad regimes, and/or they are more concerned with understanding how institutions mediate associations between variables at the microlevel in the form of cross-level interaction effects (Gingrich and Ansell 2012; Busemeyer 2013; Jordan 2013; Zhu and Lipsmeyer 2015).

The literature on institutional determinants of welfare state preferences draws on the notion of policy feedback (Pierson 1993; Mettler and Soss 2004; Soroka and Wlezien 2010; Svallfors 2010; Campbell 2012; Jordan 2013; Kumlin and Stadelmann-Steffen 2014). In an early conceptual contribution to this literature, Pierson (1993, 624) famously distinguished between "resource/incentive" and "interpretive" feedback effects. In the former case, welfare institutions create material incentives for citizens to support the continued existence (or even expansion) of certain social policy programs, e.g. pensioners support more generous pensions, the unemployed support a more generous unemployment insurance scheme. Thus, this argument is closely linked to accounts that emphasise the role of material self-interest in shaping attitudes and preferences. In contrast, "interpretive" effects concern the "impact of policies on the cognitive processes of social actors" (Pierson 1993, 610). Hence, institutions also shape cognitive and, one could add, normative expectations of citizens (Svallfors 2010) regarding the role of the welfare state both in society and in their individual lives. In the empirical analysis below, we distinguish between these two feedback mechanisms by assessing whether fairness perceptions are influenced by the actual socio-economic characteristics of individual respondents or only by the traits of hypothetical individuals in the vignettes. The former hints at the presence of resource-based feedback, whereas the latter points to the importance of interpretive feedback.

More recent work on policy feedback has provided additional insights into which features of the institutional context are more important than others. For instance, Soss and Schram (2007) argued that policy feedback is more likely when policies combine high visibility with high proximity, i.e. a small regional or social or other distance between citizens and the policy in question. Gingrich and Ansell (2012) added that the strength of policy feedback also depends on the linkages between policies and labor-market risks, whereas Kumlin (2014) showed that benefit generosity (in his case, the generosity of unemployment insurance) matters as well. Gingrich (2014) confirmed that the visibility of welfare state policies also affected the degree to which economic and social policy preferences matter with regard to vote choices. For the present article, the visibility and proximity of social policies are most important. Clearly, in the case of social services such as childcare which are delivered and - in our case - financed locally, we would expect strong policy feedback effects.

Besides improving scholarly knowledge about feedback mechanisms, recent work has also challenged Pierson's (1993) original claim that feedback effects are predominantly self-reinforcing, i.e. congruent with existing institutions. Increasingly, scholars have pointed out that institutions can also create feedback effects, which in the long run undermine rather than reinforce existing institutions (Streeck and Thelen 2005; Soroka and Wlezien 2010; Weaver 2010; Jacobs and 
Weaver 2015). Thus, if citizens critically evaluate and assess a given set of policies, they might demand policies which support a change in the prevailing status quo rather than simply reinforcing it. Work on citizens' perceptions of the performance of the welfare state, for instance, showed that citizens were well able to distinguish between abstract demands regarding what the welfare state should do and the concrete implementation of those abstract demands (Roosma et al. 2014). Popular attitudes might well be congruent with some aspects of prevailing policies and institutions, while at the same time, citizens might demand change regarding other aspects.

Moving from the broader literature on welfare state attitudes and policy feedback to the specific subject of childcare, we note a relative dearth of studies on public opinion on childcare policies despite the wealth of scholarship on social policy attitudes in general. This largely reflects the lack of survey data on childcare policies in existing international surveys, which are mostly concerned with the traditional parts of the welfare state such as pensions, labour-market policy or health care. There are, however, a few exceptions: a number of studies analysed public opinion on childcare policies across a larger number of OECD (Organisation for Economic Co-operation and Development) countries (Goerres and Tepe 2010, 2012a, 2012b, 2013; Meuleman and Chung 2012; Guo and Gilbert 2014; Chung and Meuleman 2017): there was overall widespread support for these policies, and ideology, in terms of egalitarian and gender attitudes, matters more than material self-interest as a determinant of individual-level support. These findings can be broadly replicated in studies that focus on particular countries; e.g. Henderson et al. (1995) and Bolzendahl and Olafsdottir (2008) for the United States; Goerres and Tepe (2012a) for Germany and Ellingsaeter et al. (2017) for Norway. A second common finding is that once established, childcare policies create "self-reinforcing policy feedback effects" in the sense that public support for further government involvement in the provision of childcare increases (Hedegaard and Larsen 2014; Ellingsaeter et al. 2017).

A significant shortcoming of this existing research is that it is mostly focused on exploring policy preferences at a rather abstract level. Typical questions on the welfare state in the European Social Survey or in the various modules of the International Social Survey Programme concern preferences in various areas of government spending and government responsibility or involvement without clarifying what kind of involvement is meant and how exactly public monies should be spent. To a great extent, this is of course related to the fundamental problem that a higher degree of specificity in question wording would endanger the comparability of responses across countries since the individual country contexts are so different. More importantly for the purpose of this article, there are no straightforward questions about the citizens' attitudes on whether they regard paying for a particular service such as childcare as fair. In addition, commonly used survey designs would have difficulty in assessing this issue because citizens' responses could be influenced too much by their respective personal situations. By using vignettes to measure citizens' fairness perceptions of different fee levels, we provide a new perspective on the study of public opinion on childcare policies specifically, and on welfare state policies more generally. 


\section{Theoretical expectations and hypotheses}

Our analysis essentially centres on the question of whether popular attitudes towards a particular policy are congruent with the prevailing institutional context or not. This in turn provides insights into whether policy feedback (in that particular case) exhibits a self-reinforcing or self-undermining dynamic. Furthermore, by being able to determine the association between the characteristics of hypothetical individuals in vignettes and the characteristics of the actual respondents, our study contributes to a better understanding of the relative importance of interpretive and resource-based feedback mechanisms. We focus on a particular policy in a local context. This policy is highly visible as childcare fees directly affect parents and are regularly debated in the city council and in the local newspapers. Therefore, we expect strong feedback effects in general, allowing us to tease out the previously mentioned mechanisms more easily than in a study of abstract preferences at the national level.

We focus on two issues: first, the level of fees that on average would be considered as fair by respondents, and second, the fee structure, in particular whether fees should be dependent on parents' income and family situations or not. Compared to traditional social policies, these institutional factors correspond to welfare state generosity (lower childcare fees imply a more "generous" provision of social services) and degree of regressivity (if fees are strongly dependent on parental income, the scheme is more progressive, i.e. poorer citizens are relatively better off). Empirically, we capture attitudes towards the fee structure by assessing which characteristics of the (fictitious) parental background would influence fairness perceptions of the level of fees. This approach is preferable to asking citizens directly for their preferences on fee structures because it requires less knowledge about the technical details of fee schemes. It also allows us to assess the impact of a broader set of characteristics on fairness perceptions of fees, for instance religious or migration background and employment status.

\section{Fee levels}

Plausibly, citizens might support a policy of no childcare fees. If citizens believe that the provision of childcare services falls within the broad remit of the welfare state, it should be financed from general tax revenues and therefore "free" at the point of delivery, just like other welfare state services. In the German welfare state, paying fees for welfare services at the point of delivery is very uncommon, in particular in the field of education. For instance, when several Länder governments introduced moderate tuition fees some years ago they were highly unpopular and triggered resistance not only from students but also from the wider public (Garritzmann 2015, 2016). German citizens dislike paying additional fees for social services they consider to be part of the universal welfare state package.

This logic could also apply to the case of early childhood education and care. Families with young children might be regarded as particularly deserving beneficiaries of social services, recognising the valuable contribution of young parents to societal well-being and future economic development. Even though knowledge about the beneficial long-term effects of early investments in childcare (EspingAndersen 2002; Heckmann 2006) might not necessarily be widely distributed in the general public, it is plausible to assume that citizens are aware of the significant mismatch between the demand for childcare on the part of parents and the supply 
of places. This should have a positive impact on citizens' support for an expansion of childcare opportunities, including a lower level of fees.

There are also, however, plausible reasons why citizens might be more willing to consider fees as fair in the case of childcare services compared to other welfare state services. The first is that a constituency benefiting from a lower level of fees does not have a lot of political power, if only for the simple fact that it is relatively small (families with preschool children) compared to the constituencies of the traditional sectors of the welfare state (e.g. pensions, health care, labour-market policy). Furthermore, in spite of significant advances in the expansion of family policy and institutionalised childcare options in recent years (Fleckenstein et al. 2011), a high proportion of parents still do not send their small children to daycare institutions due to the persistence of traditional family values and the male-breadwinner model as a normative reference point. ${ }^{1}$ Participation in ECEC is also correlated with socio-economic background (Van Lancker 2013). Hence, those parents who enrol their young children in ECEC institutions tend to be the wealthier ones, so that the general perception might be that they can and should pay for these services.

Over time, this constituency of wealthier parents might actually develop an interest in maintaining a certain level of fees themselves as these fees might help to maintain a certain selectivity in ECEC institutions. Additional revenue from fees could also be used to improve the quality of service delivery. Finally - and this is a specific issue related to our case selection - the close proximity of Konstanz to Switzerland, where childcare fees are substantially higher, could also affect fairness perceptions regarding the fee level. More specifically, citizens of Konstanz could be willing to accept a significantly higher level of fees compared to other German cities. At the same time, the fee level in Konstanz is relatively low compared to the average of German cities as well as to the average of neighbouring cities. Hence, if fairness perceptions of fee levels are significantly above the current level in Konstanz, this would indicate regional spillover effects from neighbouring German or Swiss cities.

These arguments can be distilled into two competing hypotheses:

H1a: The mean level of fair fees is close to zero.

This would reflect the local public's demand for a system that is not fee-based and thus independent of characteristics of the child's household.

H1b: The mean level of fair fees is well above zero.

This would indicate that the residents generally accept a fee-based system. A mean of fair fees close to the actual feel level implies a reinforcing feedback effect.

\section{Fee structure}

The current fee structure in Konstanz is very simple in the sense that the fee level is not dependent on parental income at all (with the exception of parents with very

\footnotetext{
${ }^{1}$ According to the latest figures of the Bildungsbericht, the share of children below the age of 3 in daycare institutions is $51.9 \%$ in Eastern Germany and $28.2 \%$ in Western Germany (figures for 2015, Bildungsbericht 2016, 2-3).
} 
low incomes). Parents pay lower fees if they have more than one child in childcare, but as we focus on fairness perceptions of childcare fees for the first-born child only, we neglect this factor. Hence, if self-reinforcing feedback effects dominate, we should observe no association between parental characteristics in the vignettes and perceptions of fair fees, which is akin to a flat-fee model. Even though this flat-fee model is not very common, there are a number of examples of fees for public services that are income-independent, e.g. tuition fees for higher education in Germany. Furthermore, citizens of Konstanz might simply have become accustomed to this model and have accepted it as legitimate. In contrast, if the characteristics of parents in the hypothetical vignettes are associated with fair fee perceptions, this would indicate the presence of self-undermining feedback effects, i.e. a preference for changing the status quo of the fee system in Konstanz.

This leads to another pair of competing hypotheses:

H2a: None of the vignette characteristics of the hypothetical families has a marginal effect that is statistically different from zero.

This hypothesis would support the self-reinforcing feedback effect of the flat-fee model.

H2b: At least one of the vignette characteristics of the hypothetical families has marginal effects that are statistically different from zero.

This hypothesis would reflect a self-undermining policy feedback effect in the locality due to other outside policy influences.

We now discuss in detail several potential parental characteristics which could influence fairness perceptions of fees: parental income, household composition, employment status and cultural predispositions.

\section{Parental income}

The public might consider it fair when wealthier parents contribute more to the financing of childcare, whereas higher fees for poorer parents would be considered unfair. Citizens could support income-dependent fees out of simple self-interest, e.g. the respondent's actual income could influence her fairness perceptions of the fee structure so that the poor demand income-dependent fees, whereas the rich oppose this fee model. However, since we are dealing with hypothetical characteristics of individuals in the vignettes, citizens might regard an incomedependent fee structure as fair, regardless of their individual situation. This view could be driven by "spillover" feedback effects, i.e. normative expectations regarding the financing of childcare policies that citizens develop by being exposed to regional- or national-level discourses which provide a frame of comparison beyond the local context. As income-dependent childcare fees are more common across Germany than income-independent fees, this kind of normative spillover effect could be at work in Konstanz. "Normative" feedback effects might also occur because the financing logic of the insurance-based German welfare state builds on the notion that an individual's contributions to social insurance and other welfare state schemes depends on the individual's income and wealth.

H3: The marginal effect of income of the hypothetical family is statistically larger than zero. 


\section{Household composition}

Citizens could regard lower fees for single parents as fair and would demand higher fees from dual-earner households, because single parents are more dependent on the public provision of childcare services and could therefore be regarded as more deserving recipients of services. Alternatively, if parents can rely on family members such as grandparents to help out with child-rearing, they might be expected to pay higher fees because they are richer in resources beyond just income (see e.g. Goerres and Tepe 2010, 2012b).

H4: The marginal effect of single parents compared to two-parent families is statistically smaller than zero.

H5: The marginal effect of having grand-parents for help is statistically larger than zero.

\section{Employment status}

The expectations about the impact of employment status are rather ambivalent. If one parent stays at home while the other works, citizens might consider it fair if this type of male/female breadwinner household pays higher fees because it is less dependent on institutionalised forms of childcare. Alternatively, citizens might think the contribution of (one of) the parents to child-rearing should be "rewarded" with lower fees. In summary, we would expect that individuals would determine a discount or a premium based on their perception of households' perceived levels of resources in terms of money and intrafamilial help.

H6: The marginal effects of parental employment status variables are statistically different from zero.

\section{Cultural predispositions}

Since childcare is provided locally, citizens might consider it fair if families who recently moved to the city from other places in the country, or even from abroad, should pay higher fees compared to local citizens. Furthermore, in a country like Germany, many childcare institutions are run by private providers, particularly churches, which is in line with Germany's "conservative" welfare state model. Even though we only focus on fees for public institutions in this article, we suggest that the religious denomination of parents might affect perceptions of deservingness of childcare fees as well. In particular, families affiliated with a non-Christian faith, or who do not belong to a church, might be expected to pay higher fees for childcare compared to Christian families.

H7: The marginal effects of variables measuring roots and religion are statistically different from zero.

\section{Respondent variables versus vignette variables}

Besides the vignette variables, the actual characteristics of respondents might influence their fairness perceptions as well. As mentioned above, distinguishing between the hypothetical characteristics of parents in the hypothetical vignettes on the one hand and the actual characteristics of respondents on the other allows 
differentiating between interpretive and resource-based feedback effects. A resource-based feedback mechanism would be indicated if the actual characteristics of respondents were more influential determinants of fairness perceptions compared to the hypothetical traits from the vignettes. In contrast, if only hypothetical vignette traits matter, strong interpretive feedback effects would be indicated because respondents' fairness perceptions are shaped by abstract normative considerations rather than by their own personal situation. For reasons of space, we focus on the potential impact of the respondent's socio-economic situation (income), while discussing further variables in an exploratory manner in the empirical analysis. According to the logic of resource-based policy feedback, the respondent's actual income should increase her opposition to income-dependent fee models, i.e. richer citizens should be less likely to consider higher fees as fair for rich households. Normative feedback effects, however, might dominate selfinterest-based conceptions of feedback. Given the prevalence of the incomedependent fee model in German municipalities, citizens might consider it a fair policy, independent of their own socio-economic situation.

This leads to the last, competing hypotheses.

H8a: The marginal effects of the respondent-level variables have a greater total impact - measured as the $R^{2}$ increase in the regression models - than the vignette variables.

This would mean that resource-based effects have a greater influence.

H8b: The marginal effects of the respondent-level variables have a smaller total impact - measured as the $R^{2}$ increase in the regression models - than the vignette variables.

This would imply that normative effects have a greater influence.

\section{Data and methods}

\section{The local context}

Our survey was conducted in the Southern German town of Konstanz. Focussing on a particular local context as is done in this study keeps a number of context conditions constant and therefore allows for a detailed analysis of feedback effects at the individual level and - given the concentrated sample in one locality - more powerful statistical analysis. The obvious disadvantage is that macro-level effects cannot be explored empirically even though the findings allow us to put forward new expectations for a comparative study.

In 2014, Konstanz had about 83,000 inhabitants. Its foreign population is relatively high at $13.7 \%$ due to the fact that Konstanz is a university town. It also lies on the border with Switzerland and has a considerable price differential, making it attractive to live in Germany and earn an income in Switzerland. Konstanz is a rich city (see City of Konstanz 2016). In 2012, the inhabitants of the district had a mean disposable income of about 22,000 $€$ and a gross domestic product per capita of about $57,000 €$. The unemployment rate in Konstanz was $4.4 \%$ compared to $7.5 \%$ for Germany overall.

In 2015, there were 555 children below the age of three attending childcare institutions, which represented $36.6 \%$ of all children of that age. For children 
between the ages of 3 and 6 , the attendance rate in public kindergarten was $93.9 \%$, a typical rate for West German urban areas with strong local economies (City of Konstanz 2016). Most facilities for nurseries/childcare (below the age of 3 ) and kindergarten (between 3 and 6) in Konstanz are public in the sense that they receive funding through the public system even though the organisational responsibility may be in the hands of private actors such as churches.

Childcare fees vary across local communities as well as across states. In 2014, Konstanz had a childcare fee system in place that is relatively rare across Germany. Unless parents were dependent on social assistance, fees for kindergarten were calculated independently of parental income. The fee levels varied across different municipal institutions as well as depending on the composition of the group (small children versus all children). For all-day care of a first child below the age of 3 , fees varied between $126 €$ and $220 €$ per month, with an estimated average of $200 €$ (City of Konstanz 2011, 2015, 4). In comparison to other cities in the state of Baden-Württemberg and to other municipalities in the region, the fee level in Konstanz was significantly below average. This is why in 2015 (i.e. after the field period of our survey), the city council decided to raise the fee level, so that the range in public institutions was then between $234 €$ and $274.50 €$. During this political debate, there was some discussion in the local newspaper about the possibility of introducing income-dependent fees, ${ }^{2}$ but up to March 2018 this had not led to any policy changes.

\section{The vignette study}

We ran a factorial survey experiment in which we presented a representative sample of citizens from Konstanz with different "vignettes" to obtain a better measure of their fairness perceptions about the fee level and the structure of the childcare fee system. The difference from conventional survey designs was that respondents were asked to evaluate a hypothetical situation, which usually is different from their own personal situation. Although individual respondent characteristics might still matter to some extent, this research design was particularly well-suited for identifying abstract policy preferences independent of the respondents' personal situation. Factorial survey experiments and conjoint analyses are not yet widely applied in the field of comparative welfare state research, but they have several advantages compared to traditional surveys, in particular because they allow for the manipulation of multiple treatment conditions (see Hainmueller et al. 2014; Auspurg and Hinz 2015; Hainmueller et al. 2015 for accessible introductions). There are some recent examples in political economy and welfare state research that indicate a growing interest in this methodological approach and that demonstrate its applicability and usefulness. For instance, Gallego and Marx (2017) analyse popular preferences for different kinds of labor-market policies, paying particular attention to the potential influence of trade-offs. Bansak et al. (2016) and Hainmueller and Hopkins (2015) study public attitudes towards migrants and asylum seekers.

The field period for the vignette study was between 17 October and 26 December 2014. The sample was randomly drawn from the official resident register in which all residents in Germany are obliged to register. The respondents were

\footnotetext{
${ }^{2}$ Südkurier (16 August 2014, 21): "Das müssen Eltern künftig zahlen: Stadt sucht neues Modell für KitaGebühren”.
} 
part of a long-term panel sample with regular updates as part of a collaborative project between the university and Konstanz (Konstanzer Bürgerbefragung). The survey was conducted online. Ideally, the sample represented the resident population of Konstanz aged 18 and above, but it was somewhat distorted in comparison to the general population in the sense that young, better-educated and politically more interested people were overrepresented. In contrast, individuals with foreign citizenship, and those living in one-person households, were underrepresented. Further details can be found in Appendix A. The respondents lived in 14 areas of Konstanz that they identified themselves in the survey. Since the sample was based on "persons-living-at-addresses" in the register, the areas provided a context for the sample because the respondents actually resided in those areas.

The vignette describes a family with a 2-year-old first child who is attending a public childcare facility in Konstanz. The respondents were asked to rate the fairness of an indicated monthly fee for a fulltime place at the facility (excluding the cost of meals). We used the common bipolar 11-point scale, where the value of "0" is located in the middle and is equivalent to an assessment of the fee as "Fair". Values ranging from " -1 " to " -5 " indicate various degrees of "Unfairly too low", and the values of " +1 " to " +5 " various degrees of "Unfairly too high". If respondents did not choose the mid-point, they were given the opportunity in a second question to indicate the fee that they considered fair. Hence, for each respondent, we either have the accepted fair fee or the fair fee amount indicated by him or herself. Each respondent was given a deck of five vignettes and each had different characteristics. Details about the construction of the vignette universe and the decks can be found in Appendix B. A screenshot of the vignette is in Appendix C.

We created a new variable "fair fee", which we employed as the dependent variable in the analysis. The value of this variable was either equal to the originally displayed fee, if it was considered fair, or equal to the new fee level entered by the respondent herself. For $26.1 \%$ of all ratings, we took the numerical value of the fee level that was given in the respective vignette if it was rated "fair" (between $0 €$ and $500 €$, see black columns in Figure 1). For the remaining 73.9\%, we took the fee level that the respondent indicated as a fair fee level for that situation. The resulting variable fair fee estimate varies between $0 €$ and 5,000 $€$. Seven estimates are clear outliers at 1,400-5,000 $€$ and have been deleted from the analysis. We included a technical control variable that flags whether the respondent rated the original fee level as fair or whether she entered a new value. Figure 1 shows the resulting dependent variable and highlights the number of ratings at $0 €, 100 €, 200 €, 300 €$, $400 €$ and $500 €$ that were accepted as fair.

The vignette has eight dimensions: (1) the fee, as discussed above $(0 €, 100 €$, $200 €, 300 €, 400 €$ and $500 €$ ); ${ }^{3}$ (2) the household situation (child lives with single mother, child lives with single father, child lives with both parents); (3) the mother's involvement with the formal labor market (looking for a job, housewife, working part time, working full time); (4) the father's involvement with the formal labour market (looking for a job, househusband, working part time, working full time); (5) familial support (grandparents can help out in everyday life, grandparents cannot help out in everyday life); (6) net household income [for a single-

\footnotetext{
${ }^{3}$ The range of hypothetical fee levels is likely to influence the respondents' assessment of a fair fee level, but to a large extent this problem is unavoidable. We provide a sufficiently broad, but not unrealistic, range of potential fee levels, i.e. the upper limit is about twice the actual current fee level.
} 


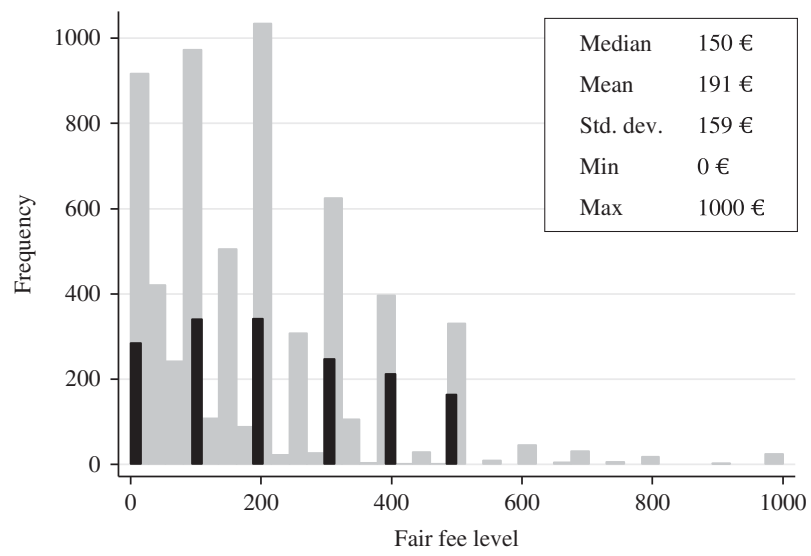

Figure 1. Distribution of the dependent variable fair fee. Note: The grey columns are frequencies of the dependent variable "fair fee". The black columns show how many given fees were considered fair.

parent household: $750 €, 1,000 €$ (roughly the median in Germany), 1,250€, $1,500 €, 2,000 €$ (75th percentile), 5,000 € (95th percentile): for a two-parent household multiply by 1.4]; (7) local roots (grew up in Konstanz, moved to Konstanz from abroad, moved to Konstanz from elsewhere in Germany); and finally, (8) the religious affiliation of the family (Christian, Muslim, no religious affiliation). The vignettes do not vary the rank of the child within the sequence of siblings (i.e. we only focus on a first-born child), the age of the child (we only concentrate on 2-year olds) and the type of the organisational structure of the kindergarten (city-run, church-run, run by a social organisation or fully private). We did not capture any characteristics of the child. This means that if respondents wanted to adjust the fee level according to the characteristics of the child, they could not do so and had to rate all vignettes in the same way.

In order to control for the respondents' personal characteristics, we included a number of respondent-level variables: gender, age in years, education (an ordinal variable of highest qualification obtained), being a German citizen by birth, the recorded number of individuals living in the respondent's household, whether there is a kindergarten-aged child in the household, and religious affiliation (Christian, other, no religious affiliation). The descriptive statistics can be found with the regression estimates in Table 1.

\section{Empirical analysis}

The average level of fees which respondents considered to be fair is $191 €$; about $2,300 €$ per year. This is, surprisingly, slightly below the actual fee level at the time of the survey. This evidence strongly suggests that the public in Konstanz accepts a positive, substantial fee for childcare services. It clearly rejects Hypothesis 1a and supports Hypothesis 1b, namely that residents accept a fee-based system at the expense of the actual service-takers. The accepted mean level is not higher than the actual level, dismissing notions of acceptance of higher fees that were in place in Switzerland, just across the border.

This is the first piece of evidence for self-reinforcing policy feedback, since citizens' perceptions are close to the actual status quo. However, this feedback 
Table 1. Random-intercept models of the dependent variable fair fee

\begin{tabular}{|c|c|c|c|}
\hline Variable Name, Mean, Minimum, Maximum & Model 1 & Model 2 & Model 3 \\
\hline Fair fee estimated by resp., $0.75,0,1$ & $\begin{array}{c}21.35^{\star \star \star} \\
{[4.46]}\end{array}$ & $\begin{array}{l}12.06^{\star *} \\
{[3.72]}\end{array}$ & $\begin{array}{l}11.34^{\star *} \\
{[3.75]}\end{array}$ \\
\hline \multicolumn{4}{|l|}{ Vignette variables } \\
\hline Income in $000 €, 1.84,0.75,5$ & & $\begin{array}{c}52.87^{\star \star \star} \\
{[1.10]}\end{array}$ & $\begin{array}{c}53.34^{\star \star \star} \\
{[1.10]}\end{array}$ \\
\hline Single parent, $0.50,0,1$ & & $\begin{array}{c}-33.28^{* \star \star} \\
{[2.94]}\end{array}$ & $\begin{array}{c}-33.74^{\star \star \star} \\
{[2.95]}\end{array}$ \\
\hline \multicolumn{4}{|l|}{ BL mother homemaker } \\
\hline mother job-seeker, 0.25, 0, 1 & & $\begin{array}{l}-4.16 \\
{[4.18]}\end{array}$ & $\begin{array}{l}-3.09 \\
{[4.20]}\end{array}$ \\
\hline mother working pt, $0.25,0,1$ & & $\begin{array}{l}-1.04 \\
{[4.18]}\end{array}$ & $\begin{array}{l}-0.27 \\
{[4.20]}\end{array}$ \\
\hline mother working $\mathrm{ft}, 0.26,0,1$ & & $\begin{array}{l}-4.87 \\
{[4.14]}\end{array}$ & $\begin{array}{l}-3.24 \\
{[4.17]}\end{array}$ \\
\hline \multicolumn{4}{|l|}{ BL father homemaker } \\
\hline father job-seeker, 0.24, 0, 1 & & $\begin{array}{l}-7.18 \\
{[4.20]}\end{array}$ & $\begin{array}{l}-6.47 \\
{[4.22]}\end{array}$ \\
\hline father working $\mathrm{pt}, 0.26,0,1$ & & $\begin{array}{l}-2.24 \\
{[4.16]}\end{array}$ & $\begin{array}{l}-1.84 \\
{[4.18]}\end{array}$ \\
\hline father working $\mathrm{ft}, 0.26,0,1$ & & $\begin{array}{c}7.74 \\
{[4.16]}\end{array}$ & $\begin{array}{c}6.98 \\
{[4.18]}\end{array}$ \\
\hline Help from grand-parents available, $0.50,0,1$ & & $\begin{array}{l}9.56^{\star \star} \\
{[2.92]}\end{array}$ & $\begin{array}{l}9.51^{\star *} \\
{[2.94]}\end{array}$ \\
\hline \multicolumn{4}{|l|}{$\mathrm{BL}$ roots elsewhere } \\
\hline roots in Konstanz $0.33,0,1$ & & $\begin{array}{l}-7.15^{\star} \\
{[3.55]}\end{array}$ & $\begin{array}{l}-5.62 \\
{[3.57]}\end{array}$ \\
\hline roots abroad, $0.32,0,1$ & & $\begin{array}{l}-5.40 \\
{[3.58]}\end{array}$ & $\begin{array}{l}-4.89 \\
{[3.60]}\end{array}$ \\
\hline \multicolumn{4}{|l|}{ BL nonaffiliated } \\
\hline Christian family, 0.34, 0, 1 & & $\begin{array}{c}3.72 \\
{[4.49]}\end{array}$ & $\begin{array}{c}2.71 \\
{[4.52]}\end{array}$ \\
\hline Muslim family, $0.35,0,1$ & & $\begin{array}{c}6.52 \\
{[4.50]}\end{array}$ & $\begin{array}{c}6.16 \\
{[4.53]}\end{array}$ \\
\hline \multicolumn{4}{|l|}{ Respondent variables } \\
\hline Household monthly income in euro & & & $\begin{array}{c}0.00 \\
{[0.00]}\end{array}$ \\
\hline Age & & & $\begin{array}{c}-0.58^{\star \star \star} \\
{[0.17]}\end{array}$ \\
\hline Female gender, 0.48, 0, 1 & & & $\begin{array}{c}-10.09 \\
{[5.63]}\end{array}$ \\
\hline Highest educational level, 7.0, 1, 9 & & & $\begin{array}{l}-2.46 \\
{[1.97]}\end{array}$ \\
\hline Kindergarten child in hh, $0.08,0,1$ & & & $\begin{array}{c}-11.14 \\
{[9.86]}\end{array}$ \\
\hline Logged number of hh members, $0.65,0,1.9$ & & & $\begin{array}{c}-16.88 \\
{[8.68]}\end{array}$ \\
\hline DE citizen by birth, $0.89,0,1$ & & & $\begin{array}{c}3.57 \\
{[9.30]}\end{array}$ \\
\hline \multicolumn{4}{|l|}{ BL nonaffiliated } \\
\hline Christian, 0.65, 0, 1 & & & $\begin{array}{l}13.52^{\star} \\
{[6.02]}\end{array}$ \\
\hline Other Believer, 0.02, 0, 1 & & & $\begin{array}{l}-16.40 \\
{[19.30]}\end{array}$ \\
\hline \multicolumn{4}{|l|}{ Contextual variables } \\
\hline Purchase power in ' $000 €^{\prime}, 19.6,14.2,27.6$ & & & $\begin{array}{c}0.92 \\
{[1.18]}\end{array}$ \\
\hline$\%$ of $0-3$-year olds in childcare & & & $\begin{array}{l}-0.17 \\
{[0.38]}\end{array}$ \\
\hline
\end{tabular}


Table 1. (Continued)

\begin{tabular}{lccc}
\hline Variable Name, Mean, Minimum, Maximum & Model 1 & Model 2 & Model 3 \\
\hline Inhabitants per habitable acre, 68, 4.5, 100.1 & & & 0.12 \\
& & & {$[0.16]$} \\
\% of foreigners, 0.129, 0.049, 0.267 & & & -104.00 \\
& $185.83^{\star \star \star}$ & $106.35^{\star \star \star}$ & {$[108.50]$} \\
Constant & {$[2.97]$} & {$[6.33]$} & $131.50^{\star \star}$ \\
& 6,268 & 6,268 & {$[43.94]$} \\
Observations & 0.220 & 0.342 & 0,108 \\
Intraclass correlation coefficient & 0.001 & 0.343 & 0.344 \\
$R^{2}$ within & 0.047 & 0.028 & 0.350 \\
$R^{2}$ between & 0.008 & 0.221 & 0.049 \\
$R^{2}$ overall & & & \\
\hline
\end{tabular}

Note: Standard errors in brackets.

Additional models show that the effect of income of the vignette family is linear, as modelled here. $\mathrm{p}$-Value of a two-sided test of the null that $\beta$ is equal to 0 .

${ }^{\star} \mathrm{p}<0.05,{ }^{\star \star} \mathrm{p}<0.01,{ }^{\star \star \star} \mathrm{p}<0.001$.

effect is self-reinforcing only in the sense that German citizens have come to accept paying fees for childcare, even though paying fees for social services is otherwise rather uncommon in the German welfare state regime. The acceptance of a significant level of fees in the case of childcare might be related to the fact that in the public's perception, attending kindergarten is more than just education; it also allows parents to pursue work, in addition to providing children with educational possibilities. For that reason, the public may be more willing to accept childcare fees since they are balanced out by enhanced employment opportunities. Furthermore, the expansion of opportunities in early childcare is a recent phenomenon; citizens might be more willing to support the expansion of new services with additional discretionary spending on their part, implicitly acknowledging the limitations on general welfare spending.

The standard deviation in the "perceived fair fee level" is relatively high at $159 €$, another piece of evidence against the acceptance of a flat-fee system. This heterogeneity in acceptable fee levels is related to varying vignette traits, although not all of the vignette dimensions produce significant results. In the following statistical analysis, we correct for multiple ratings from the same respondent by using a multi-level random-intercept model. We start with the empty null model (Model 1), which just contains the estimate of an intercept for every respondent as well as a (technical) dummy variable indicating whether the fee level is provided by the respondent herself or is perceived as fair (see discussion above). Then, we estimate the model with all vignette traits (Model 2), followed by Model 3 with vignette traits, respondent characteristics and additional contextual information from the city areas where respondents live.

Model 1 reveals an intraclass correlation coefficient of $22.0 \%$ in a theoretically empty model. This means that the ratings per individual are moderately similar to one another when we do not control for any particular characteristics of the respondents' or the vignette traits. The positive and significant coefficient 21.35 of the technical dummy variable indicates that when the fee estimate is provided by the respondent herself, the perceived fair fee level is slightly higher compared to the situation when it was first given in the vignette and then perceived as fair. 
Table 2. Overview of hypotheses and the empirical results

\begin{tabular}{|c|c|c|}
\hline Hypothesis & & $\begin{array}{l}\text { Failed to } \\
\text { Reject }\end{array}$ \\
\hline $\mathrm{H} 1 \mathrm{a}$ & The mean level of fair fees is close to zero & No \\
\hline $\mathrm{H} 1 \mathrm{~b}$ & The mean level of fair fees is well above zero & Yes \\
\hline $\mathrm{H} 2 \mathrm{a}$ & $\begin{array}{l}\text { None of the vignette characteristics of the hypothetical families has marginal } \\
\text { effects in the regression models that are statistically different from zero }\end{array}$ & No \\
\hline $\mathrm{H} 2 \mathrm{~b}$ & $\begin{array}{l}\text { At least one of the vignette characteristics of the hypothetical families has } \\
\text { marginal effects in the regression models that are statistically different from } \\
\text { zero }\end{array}$ & Yes \\
\hline H3 & $\begin{array}{l}\text { The marginal effect of income of the hypothetical family is statistically larger } \\
\text { than zero }\end{array}$ & Yes \\
\hline $\mathrm{H} 4$ & $\begin{array}{l}\text { The marginal effect of single parents compared to two-parent families is } \\
\text { statistically smaller than zero }\end{array}$ & Yes \\
\hline H5 & $\begin{array}{l}\text { The marginal effect of having grand-parents for help is statistically larger than } \\
\text { zero }\end{array}$ & Yes \\
\hline H6 & $\begin{array}{l}\text { The marginal effects of parental employment status are statistically different } \\
\text { from zero }\end{array}$ & No \\
\hline $\mathrm{H} 7$ & $\begin{array}{l}\text { The marginal effects of variables measuring roots and religion are statistically } \\
\text { different from zero }\end{array}$ & No \\
\hline $\mathrm{H} 8 \mathrm{a}$ & $\begin{array}{l}\text { The marginal effects of the respondent-level variables have a greater total } \\
\text { impact - measured as the } R^{2} \text { increase in the regression models - than the } \\
\text { vignette variables }\end{array}$ & No \\
\hline $\mathrm{H} 8 \mathrm{~b}$ & $\begin{array}{l}\text { The marginal effects of the respondent-level variables have a smaller total } \\
\text { impact - measured as the } R^{2} \text { increase in the regression models - than the } \\
\text { vignette variables }\end{array}$ & Yes \\
\hline
\end{tabular}

In Model 2, the vignette variables are added. Including vignette traits significantly increased the goodness of fit: The $R^{2}$ of within-variation jumps to $34.3 \%$ of explained variance; the intraclass correlation coefficient increases to $34.2 \%$, meaning that respondent answers are more similar when we take into consideration the large variance in ratings between vignettes. The core finding of the analysis is the strong support for a fee structure, which takes into account monetary or other resources in assessing the level of fair fees. We can thus reject Hypothesis 2a (vignette traits do not matter because all children/families are perceived as equal in terms of fees) and give more credence to Hypothesis $2 \mathrm{~b}$. Residents causally react in their ratings to the traits of the families described.

By far the strongest associations within the vignettes are related to parental income. Model 2 shows that an increase in (hypothetical) household income by $1,000 €$ is associated with an increase of $53 €$ in perceived fair monthly fees for childcare. This is strong support for Hypothesis 3.

The results also show that respondents take into account other resources besides income in their assessment of a fair fee level. Being a single parent is associated with a "discount" of $33 €$ in the perceived level of fair fees, compared to two-parent households, supporting Hypothesis 4. Alternatively, having "grandparents available for help" has an effect as well: In this case, respondents would consider an additional fee of $9 €$ per month as fair, supporting Hypothesis 5. This suggests a broader consideration of resources among Konstanz residents which goes beyond just monetary resources. Based on fairness perceptions, single parenthood qualifies for lower childcare fees, whereas families with familial support from grandparents are expected to pay more. Comparatively speaking, the latter top-up on fees is significantly smaller than the "discount" for single parents, however. 
Surprisingly, the employment status of the mother does not matter. In fact, an $F$-test shows that the three variables for the employment status of the mother (capturing working part-time, working full-time looking for a job and homemaker) can be excluded from the model without a significant drop in the statistical fit of the model.

The finding is slightly different for the employment status of the father. These variables (father homemaker, father job-seeker, father working part-time, father working full-time) cannot be dismissed based of the result of an F-test. In the eyes of the respondents, fathers who are unemployed and looking for a job warrant a fee for their child that is $13 €$ lower than fathers who work full time. Thus, there is some evidence that respondents are willing to support a "discount" of fees, when the (presumably) male breadwinner's employment opportunities are compromised. In sum, however, the composition of earners in the vignette family does not impact the ratings, thus rejecting Hypothesis 6.

The last set of variables can be dismissed as lacking any value for explaining statistical results. Whether the family in the vignette comes from Germany, from Konstanz or from abroad, does not matter. The religious affiliation of the child makes no difference either. The F-test suggests that we could drop these four variables without comprising the fit of the model. ${ }^{4}$ From a political perspective, these nonfindings are positive news, since they indicate that the residents of Konstanz do not discriminate against foreigners, new residents or people with a non-Christian religious affiliation by demanding higher levels of childcare fees. Cultural predispositions do not have any causal impact, thus rejecting Hypothesis 7.

Model 3 introduces respondent-level and city area characteristics into the analysis. The increase in the overall $R^{2}$ between models 2 and 3 is a mere 1.2 percentage points, due to respondent-level characteristics (recall that they are uncorrelated with the vignette traits). The increase from models 1 to 2 is 21.3 percentage points - clearly much higher. Thus, we can reject Hypothesis 8a and accept Hypothesis 8b: vignette traits matter much more than respondent variables, putting an emphasis on normative rather than resource-based feedback effects.

Going into further detail, we do not find many significant associations. What is remarkable is that the respondents' income does not affect the level of fair fees, even though income is the most important vignette dimension related to fairness perceptions. This indicates a broad, cross-class consensus on the fairness of the income-dependent fee model: rich individuals are not opposed to this model, even though they would have to pay higher fees and would be disadvantaged compared to the current status quo.

Before we turn to an exploratory interaction analysis, Table 2 summarises all of our hypotheses and their evidence.

The exploratory analysis focuses first on the interaction between income as a respondent characteristic and (the fictitious) income as a vignette trait. A series of $F$-tests (see Appendix D) confirms that the association between income in the vignettes is moderated by the respondents' household income. Surprisingly, the direction of the interaction is positive: rich respondents consider even higher fees

\footnotetext{
${ }^{4}$ There is one pairwise contrast with a statistical significant difference that is small in magnitude (between those from Konstanz and those from elsewhere).
} 
to be fair compared to residents in low-income families. ${ }^{5}$ The magnitude of this effect is not huge, but it still indicates that richer Konstanz residents perceive higher levels of fees as fair compared to residents with lower incomes. At first sight, this seems to run counter to material self-interest, and it could indeed indicate altruistic behaviour. However, it may also be the case that richer citizens support and accept higher fees in order to promote quality in childcare facilities, even if this implies a higher degree of selectivity when accessing those facilities. Potentially, richer citizens might also work with different frames of reference, i.e. the rich and poor might differ in their subjective perceptions of the same fee level. Unfortunately, our data cannot tell us which of these explanations holds.

With regard to other respondent characteristics, we find that respondents who are older, live in larger households and whose religious affiliation is "other than Christian" or "nonbeliever" perceive lower childcare fees as fair. The presence of a small child in the household of the respondent does not make a difference to the perception of fairness, neither does gender. For age, we surprisingly estimate a negative coefficient that implies that older individuals are more likely to perceive lower fees as fair. This could indicate that the elderly are indeed more supportive of ensuring affordable childcare for young families. Alternatively, it could be the case that the youngest age group in the study contains a lot of individuals who do not have children of their own who do not think of Konstanz as the place to raise a family as they are students or recent graduates likely to move away soon.

The residential area variables do not yield any significant coefficients, indicating that the perceptions of fair childcare fees are not contingent on where respondents live in the city: neither purchasing power (between 14,200 $€$ and 27,600 $€$ ), the percentage of foreigners (between 4.9 and 26.7\%), the relative proportion of children in public childcare between birth and three years (between 0.0 and $79.2 \%$ ) nor population density (between 4.5 and 100.1 residents per acre of habitable area) are related to perceptions of fair childcare fees.

\section{Summary and conclusions}

In summary, our analysis reveals a number of core findings: respondents regard a level of hypothetical fees as fair which is slightly below the actual level of fees at the time of the survey. This is a strong indication of self-reinforcing policy feedback. However, at the same time, respondents' fairness perceptions indicate strong support for a fee model in which fees are dependent on income and other individual resources. This is at odds with the local fee structure, in which fees are independent of income. This finding therefore presents evidence of a selfundermining feedback dynamic, thus hinting at significant public demand for policy change. Rather than supporting the particular fee model employed in the local context, citizens support the model which is predominant in other German cities. This dynamic could be driven by regional spillover in the sense that citizens in Konstanz are regularly exposed to regional and national discourses about

\footnotetext{
${ }^{5}$ For respondents with household income 1 SD below the mean (at about 1,660 €), the coefficient estimate for the income as vignette trait is $50 €$ (SE of $1.6 €$ ), meaning that an additional $1,000 €$ of the hypothetical family income is associated with an increase of $50 €$ in perceived fair fees. For respondents with a mean household income (about $3,300 €$ ), the estimated increase is $53 €$ (SE of $1.1 €$ ). For respondents at $1 \mathrm{SD}$ above the mean, it is $57 €(\mathrm{SE}$ of $1.5 €)$.
} 
childcare fees and have come to accept the income-dependent model as a normative reference point. Alternatively, spillover could occur from other parts of the welfare state as the insurance-based model of German social policy is based on the notion that richer citizens contribute more to the financing of benefits and services than poorer citizens. Finally, the actual individual-level income of respondents does not influence their perceptions of fair fees. This is indicative of normative/ interpretive feedback effects dominating resource-based feedback.

What are the broader implications of a study of a particularly rich city in the south of Germany for the politics of childcare and welfare state reform? On the one hand, Konstanz is quite representative of many German cities confronted with a massively increased demand for the public provision of childcare. Even though the public resources are less constrained in this wealthy city compared to other German cities, our survey indicates that citizens are still willing to pay a considerable amount of fees to contribute to the financing of childcare. For policymakers who intent on expanding childcare provision without ruining public finances, this is good news.

On the other hand, Konstanz is atypical because of its wealth, its location on the border with Switzerland, and its particular childcare fee model (income-independent fees). These peculiarities offer some analytical leverage to draw broader conclusions. The widespread support for the income-dependent fee model among our survey respondents indicates significant policy feedback effects, but in a particular manner. For one, Konstanz residents support the fee model which is most common across German localities, but different from the local fee model practised in Konstanz. At the same time, the respondents did not support fee models that were completely different from the prevailing local status quo. For instance, the analysis could have revealed an average fair fee level of zero, indicating that citizens would consider as fair having access to childcare at no additional cost (the Scandinavian model). Alternatively, citizens could have been willing to pay even higher fees, as is common in neighbouring Switzerland. Instead we found that public opinion is largely congruent with prevailing policies and institutions at the national level, as argued in the policy feedback literature (Pierson 1993), but still sufficiently independent from the prevailing (local) status quo in order to promote incremental policy changes. What is also striking is that the income-dependent fee model is accepted and supported across different income categories - even the wealthy are willing to pay higher childcare fees. This might be driven by some kind of sophisticated material self-interest in quality and selectivity, or it could reflect a genuine, greater willingness among the wealthy to pay.

Supplementary material. To view supplementary material for this article, please visit https:/doi.org/ $10.1017 /$ S0143814X18000491

Data Availability Statement. Replication materials are available at the Journal of Public Policy Dataverse https://doi.org/10.7910/DVN/5EZOHY

Acknowledgements. The data collection was funded by seed money to the first-named author. Equal authors are listed alphabetically. The data collection was commissioned to and supervised by Katrin Auspurg, Sandra Walzenbach and Thomas Hinz. The content of the vignette study was the sole responsibility of the authors. The article was presented at a workshop at the University of Zürich in January 2017 and a panel at the Council for European Studies annual conference in Glasgow in July 2017, both organised 
by Silja Häusermann. The authors thank her for having provided these opportunities as well as Paul Marx and Reto Bürgisser for comments.

\section{References}

Alesina A and Angeletos GM (2005) Fairness and Redistribution. American Economic Review 95(4): 960-980.

Andreß HJ and Heien T (2001) Four Worlds of Welfare State Attitudes? A Comparison of Germany, Norway, and the United States. European Sociological Review 17(4): 337-356.

Auspurg K and Hinz T (2015) Multifactorial Experiments in Surveys: Conjoint Analysis, Choice Experiments, and Factorial Surveys. In Keuschnigg $\mathrm{M}$ and Wolbring $\mathrm{T}$ (eds.), Experimente in den Sozialwissenschaften. Baden-Baden: Nomos, 291-315.

Bansak K, Hainmueller J and Hangartner D (2016) How Economic, Humanitarian, and Religious Concerns Shape European Attitudes Toward Asylum-Seekers. Science 354(6309): 217-222.

Bildungsbericht (2016) Bildung in Deutschland 2016, http://www.bildungsbericht.de/de/bildungsberichteseit-2006/bildungsbericht-2016/pdf-bildungsbericht-2016/wichtigste-ergebnisse-bildungsbericht-2016 (accessed 21 March 2018).

Blekesaune M and Quadagno J (2003) Public Attitudes Toward Welfare State Policies: A Comparative Analysis of 24 Countries. European Sociological Review 19(5): 415-427.

Bolzendahl C and Olafsdottir S (2008) Gender Group Interests or Gender Ideology? Understanding U.S. Support for Family Policy Within the Liberal Welfare Regime. Sociological Perspectives 51(2): 281-304.

Busemeyer MR (2013) Education Funding and Individual Preferences for Redistribution. European Sociological Review 29(4): 707-719.

Busemeyer MR, Goerres A and Weschle S (2009) Attitudes Towards Redistributive Spending in an Era of Demographic Ageing: The Rival Pressures from Age and Income in 14 OECD Countries. Journal of European Social Policy 19(3): 195-212.

Campbell AL (2012) Policy Makes Mass Politics. Annual Review of Political Science 15, 333-351.

Chung H and Meuleman B (2017) European Parents' Attitudes Towards Public Childcare Provision: The Role of Current Provisions, Interests and Ideologies. European Societies 19(1): 49-68.

City of Konstanz (2011) Satzung der Stadt Konstanz über die Erhebung von Gebühren für den Besuch der städtischen Tageseinrichtungen für Kinder. Public decree by the mayor, 01-10-2011.

City of Konstanz (2015) Beschlussvorlage für den Stadtrat: Neugestaltung der Elternbeiträge für Kindertageseinrichtungen. Public document prepared for hearing in local council and the youth-support committee, 10-03-2015.

City of Konstanz (2016) Konstanz in Zahlen. Statistical Report of the City.

Cusack T, Iversen T and Rehm P (2006) Risks at Work: The Demand and Supply Sides of Government Redistribution. Oxford Review of Economic Policy 22(3): 365-389.

De La O AL and Rodden JA (2008) Does Religion Distract the Poor? Income and Issue Voting Around the World. Comparative Political Studies 41(4-5): 437-476.

Ellingsaeter AL, Kitterod RH and Lyngstad J (2017) Universalising Childcare, Changing Mothers' Attitudes: Policy Feedback in Norway. Journal of Social Policy 46(1): 149-73.

Esping-Andersen G (2002) Why We Need a New Welfare State. Oxford, New York: Oxford University Press.

Fleckenstein T, Saunders AM and Seeleib-Kaiser M (2011) The Dual Transformation of Social Protection and Human Capital: Comparing Britain and Germany. Comparative Political Studies 44(12): $1622-1650$.

Gallego A and Marx P (2017) Multi-Dimensional Preferences for Labor Market Reform: A Conjoint Experiment. Journal of European Public Policy 24(7): 1027-1047.

Garritzmann JL (2015) Attitudes Towards Student Support: How Positive Feedback Effects Prevent Change in the Four World of Student Finance. Journal of European Social Policy 25(2): 139-158.

Garritzmann JL (2016) The Political Economy of Higher Education Finance: The Politics of Tuition Fees and Subsidies in OECD Countries, 1945-2015. Basingstoke: Palgrave Macmillan.

Gingrich JR (2014) Structuring the Vote: Welfare Institutions and Value-Based Vote Choices. In Kumlin S and Stadelmann-Steffen I (eds.), How Welfare States Shape the Democratic Public: Policy Feedback, 
Participation, Voting, and Attitudes. Cheltenham, UK and Northampton, MA, USA: Edward Elgar, 93-112.

Gingrich JR and Ansell BW (2012) Preferences in Context: Micro Preferences, Macro Contexts, and the Demand for Social Policy. Comparative Political Studies 45(12): 1624-1654.

Goerres A and Tepe M (2010) Age-Based Self-Interest, Intergenerational Solidarity and the Welfare State: A Comparative Analysis of Older People's Attitudes Towards Public Childcare in 12 OECD Countries. European Journal of Political Research 49(6): 818-851.

Goerres A and Tepe M (2012a) Doing it for the Kids? The Determinants of Attitudes Towards Public Childcare in Unified Germany. Journal of Social Policy 41(2): 349-372.

Goerres A and Tepe M (2012b) The Family and the Welfare State: The Impact of Public Provision for Families on Young People's Demand for Public Childcare Across 21 Nations. In Goerres A and Vanhuysse P (eds.), Ageing Populations in Post-Industrial Democracies: Comparative Studies of Policies and Politics. London, New York: Routledge, 178-205.

Goerres A and Tepe M (2013) Für die Kleinen ist uns nichts zu teuer? Kindergartengebühren und ihre Determinanten in Deutschlands 95 bevölkerungsreichsten Städten zwischen 2007 und 2010. dms - der moderne staat 6(1): 169-190.

Guo J and Gilbert N (2014) Public Attitudes Toward Government Responsibility for Child Care: The Impact of Individual Characteristics and Welfare Regimes. Children and Youth Services Review 44, 82-89.

Hacker JS, Rehm P and Schlesinger M (2013) The Insecure American: Economic Experiences, Financial Worries, and Policy Attitudes. Perspectives on Politics 11(1): 23-49.

Hainmueller J, Hangartner D and Yamamoto T (2015) Validating Vignette and Conjoint Survey Experiments Against Real-World Behavior. PNAS 112(8): 2395-2400.

Hainmueller J and Hopkins DJ (2015) The Hidden American Immigration Consensus: A Conjoint Analysis of Attitudes Towards Immigrants. American Journal of Political Science 59(3): 529-548.

Hainmueller J, Hopkins DJ and Yamamoto T (2014) Causal Inference in Conjoint Analysis: Understanding Multidimensional Choices Via Stated Preference Experiments. Political Analysis 22, 1-30.

Heckman JJ (2006) Skill Formation and the Economics of Investing in Disadvantaged Children. Science 312, 1900-1902.

Hedegaard TF and Larsen CA (2014) How Proximate and Visible Policies Shape Self-interest, Satisfaction, and Spending Support: The Case of Public Service Provision. In Kumlin S and Stadelmann-Steffen I (eds.), How Welfare States Shape the Democratic Public: Policy Feedback, Participation, Voting, and Attitudes. Cheltenham, UK and Northampton, MA, USA: Edward Elgar, 269-288.

Henderson TL, Monroe PA, Garand JC and Burts DC (1995) Explaining Public Opinion Toward Government Spending on Childcare. Family Relations 44(1): 37-45.

Iversen T and Soskice D (2001) An Asset Theory of Social Policy Preferences. American Political Science Review 95(4): 875-893.

Jacobs AM and Weaver RK (2015) When Policies Undo Themselves: Self-Undermining Feedback as a Source of Policy Change. Governance 28(4): 441-457.

Jaeger MM (2006) Welfare Regimes and Attitudes Towards Redistribution: The Regime Hypothesis Revisited. European Sociological Review 22(2): 157-170.

Jaeger MM (2009) United but Divided: Welfare Regimes and the Level and Variance in Public Support for Redistribution. European Sociological Review 25(6): 723-737.

Jordan J (2013) Policy Feedback and Support for the Welfare State. Journal of European Social Policy 23(2): 134-148.

Kangas O (1997) Self-Interest and the Common Good: The Impact of Norms, Selfishness and Context in Social Policy Opinions. Journal of Socio-Economics 26(5): 475-494.

Kitschelt H and Rehm P (2014) Occupations as a Site of Political Preference Formation. Comparative Political Studies 47(12): 1676-1706.

Kumlin S (2014) Policy Feedback in Political Context: Unemployment Benefits, Election Campaigns, and Democratic Satisfaction. In Kumlin S and Stadelmann-Steffen I (eds.), How Welfare States Shape the Democratic Public: Policy Feedback, Participation, Voting, and Attitudes. Cheltenham, UK and Northampton, MA, USA: Edward Elgar, 181-197.

Kumlin S and Stadelmann-Steffen I (2014) Citizens, Policy Feedback, and European Welfare States. In Kumlin S and Stadelmann-Steffen I (eds.), How Welfare States Shape the Democratic Public: Policy 
Feedback, Participation, Voting, and Attitudes. Cheltenham, UK and Northampton, MA, USA: Edward Elgar, 3-16.

Margalit Y (2013) Explaining Social Policy Preferences: Evidence from the Great Recession. American Political Science Review 107(1): 80-103.

Meltzer AH and Richard SF (1981) A Rational Theory of the Size of Government. Journal of Political Economy 89(5): 914-927.

Mettler S and Soss J (2004) The Consequences of Public Policy for Democratic Citizenship: Bridging Policy Studies and Mass Politics. Perspectives on Politics 2(1): 55-73.

Meuleman B and Chung H (2012) Who should Care for the Children? Support for Government Intervention in Childcare. In Ervasti H, Goul Andersen J, Fridberg T and Ringdal K (eds.), The Future of the Welfare State: Social Policy Attitudes and Social Capital in Europe. Cheltenham, UK and Northampton, MA, USA: Edward Elgar, 107-131.

Pierson P (1993) When Effect Becomes Cause: Policy Feedback and Political Change. World Politics 45(4): 595-628.

Rehm P (2009) Risk and Redistribution: An Individual-Level Analysis. Comparative Political Studies 42(7): 855-881.

Rehm P, Hacker JS and Schlesinger M (2012) Insecure Alliances: Risk, Inequality, and Support for the Welfare State. American Political Science Review 106(2): 386-406.

Roosma F, Van Oorschot W and Gelissen J (2014) The Preferred Role and Perceived Performance of the Welfare State: European Welfare Attitudes from a Multidimensional Perspective. Social Science Research 44, 200-210.

Scheve K and Stasavage D (2006) Religion and Preferences for Social Insurance. Quarterly Journal of Political Science 1, 255-286.

Schwander H, Häusermann S and Kurer T (2015) High-Skilled Outsiders? Labor Market Vulnerability, Education and Welfare State Preferences. Socio-Economic Review 13(2): 235-258.

Soroka SN and Wlezien C (2010) Degrees of Democracy: Politics, Public Opinion, and Policy. Cambridge and New York: Cambridge University Press.

Soss J and Schram SF (2007) A Public Transformed? Welfare Reform as Policy Feedback. American Political Science Review 101(1): 111-127.

Streeck W and Thelen K (2005) Introduction: Institutional Change in Advanced Political Economies. In Streeck W and Thelen K (eds.), Beyond Continuity: Institutional Change in Advanced Political Economies. Oxford, New York: Oxford University Press, 1-39.

Südkurier (2014, 16 August). Das müssen Eltern künftig zahlen: Stadt sucht neues Modell für KitaGebühren, p. 21.

Svallfors S (1997) Worlds of Welfare and Attitudes to Redistribution: A Comparison of Eight Western Nations. European Sociological Review 13(3): 283-304.

Svallfors S (2004) Class, Attitudes and the Welfare State: Sweden in Comparative Perspective. Social Policy \& Administration 38(2): 119-138.

Svallfors S (2010) Policy Feedback, Generational Replacement, and Attitudes to State Intervention: Eastern and Western Germany, 1990-2006. European Political Science Review 2(1): 119-135.

Svallfors S (2012) Welfare States and Welfare Attitudes. In Svallfors S (ed.), Contested Welfare States: Welfare Attitudes in Europe and Beyond. Stanford, CA: Stanford University Press, 1-24.

Van Lancker W (2013) Putting the Child-Centred Investment Strategy to the Test: Evidence for the EU27. European Journal of Social Security 15(1): 4-27.

Weaver RK (2010) Paths and Forks or Chutes and Ladders? Negative Feedbacks and Policy Regime Change. Journal of Public Policy 30(2): 137-162.

Zhu L and Lipsmeyer CS (2015) Policy Feedback and Economic Risk: The Influence of Privatization on Social Policy Preferences. Journal of European Public Policy 22(10): 1489-1511.

Cite this article: Busemeyer M.R., Goerres A. 2020. Policy feedback in the local context: analysing fairness perceptions of public childcare fees in a German town. Journal of Public Policy 40: 513-533, doi:10. 1017/S0143814X18000491 